Journal of Southeast Asian

\title{
Review of T. Pho, J. N. Gerson, \& S. R. Cowan's (Eds.) (2007) Southeast Asian Refugees and Immigrants in the Mill City
}

Vichet Chhuon

University of Minnesota, vichet@umn.edu

Follow this and additional works at: https://docs.lib.purdue.edu/jsaaea

Part of the Asian American Studies Commons

\section{Recommended Citation}

Chhuon, Vichet (2008) "Review of T. Pho, J. N. Gerson, \& S. R. Cowan's (Eds.) (2007) Southeast Asian

Refugees and Immigrants in the Mill City," Journal of Southeast Asian American Education and

Advancement: Vol. 3 : Iss. 1, Article 20.

DOI: $10.7771 / 2153-8999.1116$

Available at: https://docs.lib.purdue.edu/jsaaea/vol3/iss1/20

This document has been made available through Purdue e-Pubs, a service of the Purdue University Libraries. Please contact epubs@purdue.edu for additional information.

This is an Open Access journal. This means that it uses a funding model that does not charge readers or their institutions for access. Readers may freely read, download, copy, distribute, print, search, or link to the full texts of articles. This journal is covered under the CC BY-NC-ND license. 


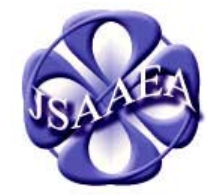

Volume 3
Journal of Southeast Asian American

Education E Advancement

WWW.JSAAEA.org
A peer-reviewed

scholarly journal

published by the

National Association

for the Education \&

Advancement of

Cambodian, Laotian, and Vietnamese Americans (NAFEA)

\section{Book Review}

Southeast Asian Refugees and Immigrants in the Mill City: Changing Families, Communities, and Institutions, Thirty Years Afterwards. Edited by Jeffery N. Gerson, Sylvia R. Cowan, and Tuyet-Lan Pho. University of Vermont Press. 250 pp. \$50.00 (Hardback). ISBN-10: 158465662X. http://www.upne.com/1-58465-662-X.html

\section{Reviewed by \\ Vichet Chhuon \\ University of California-Santa Barbara}

Past and present waves of immigration have added significantly to the numbers of immigrants in the United States. Southeast Asian families in the United States, including those from Cambodia, Vietnam, and Laos, represent some of the newest Asian immigrant populations whose experiences differ fundamentally from those of many other Asian immigrants. Unfortunately, Southeast Asian communities are still not well understood by policymakers, researchers, and practitioners. In Southeast Asian Refugees and Immigrants in the Mill City, Jeffery N. Gerson, Sylvia R. Cowan, and Tuyet-Lan Pho, have sought to narrow the gap in the literature by pulling together a collection of studies that examine the adaptation and assimilation of Southeast Asian families in Lowell, Massachusetts, a midsized city that is home to a large number of Vietnamese, Lao, and Cambodian immigrant families. Altogether, the book does a good job of describing the unique hopes and concerns of Southeast

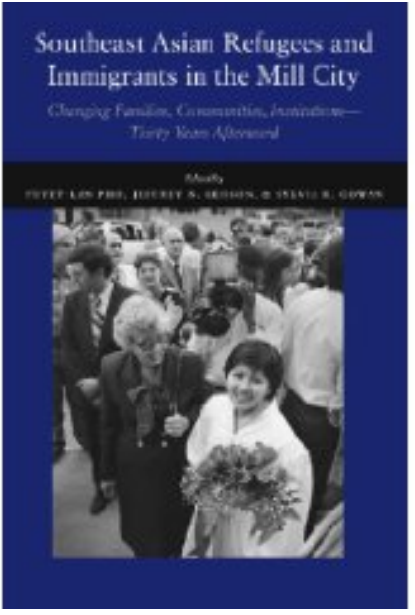
Asians living in this New England city. A diverse range of methodological approaches are represented in this volume including individual interviews, focus groups, quantitative surveys, and ethnography. Through its cautious examination of the social, political, historical, cultural, and educational changes experienced by Southeast Asians in Lowell, the volume represents an important contribution to the literature on immigrant and Southeast Asian American studies.

This book is divided unevenly into three sections that address several dimensions of life for Southeast Asians in Lowell. Part one includes an editors' introduction and two chapters that describe the settlement and resettlement of Southeast Asian immigrants to the city. In Chapter 2, Hai B. Pho argues that by focusing on Southeast Asian immigrants in this city, a broader

\section{@)}

SOMERIGHISRESERVEDReaders are free to copy, display, and distribute this article, as long as the work is attributed to the author(s) and the Journal of Southeast Asian American Education \& Advancement, it is distributed for noncommercial purposes only, and no alteration or transformation is made in the work. More details of this Creative Commons license are available at http://creativecommons.org/licenses/by-nc-nd/3.0/. All other uses must be approved by the author(s) or JSAAEA. 
understanding of the challenges and successes experienced by other immigrant communities in U.S. society can be gained. It is necessary to understand the global contexts for the movement of Southeast Asian people during the 1970s and 1980s to appreciate why these families came to Lowell. Pho's chapter begins with a brief context and history of Southeast Asians' migration to the United States between 1975 and 2000. However, it was not until after 1985 that an unexpected larger influx of secondary migration by Southeast Asians clustered in other parts of the United States that make up the concentration of Southeast Asians in Lowell today. Unfortunately, little research has examined the secondary migration of Southeast Asian populations in the United States from one locality to another. The next chapter by Jean Larson Pyle sheds light onto the phenomenon of secondary migration to Lowell. Whereas the sizeable immigration of Southeast Asians to the United States is fairly explainable, less is known about the secondary movement of these populations. Seeking to dispel misconceptions about Southeast Asian immigrants' relocation to Lowell, Pyle stated:

While it has been thought that many may have relocated to Lowell because of the relative attractiveness of public assistance in Massachusetts, the evidence does not support this. The initial newcomers exhibited low rates of reliance on public assistance: in early 1990, approximately 24 percent of the welfare families in Lowell were Southeast Asian-a percentage equivalent to their proportion of the Lowell population. (p. 28)

Instead, community members explained that other factors such as the development of an ethnic community (businesses and community organizations) were major factors for secondary migration. The construction of a Buddhist temple in a neighboring town also attracted many Southeast Asian families to resettle in Lowell. Further, employment opportunities for Southeast Asians, particularly Cambodians, were influential migration factors as some firms actively recruited and accommodated workers in spite of language barriers. Pyle argues that understanding the secondary migration of Southeast Asians to Lowell might show how immigration policies impact local economies as well as the U.S. economy broadly. Unpacking what motivates immigrants to move from one locality to another can inform policies aimed at helping immigrants adjust into U.S. society.

David Turcotte and Linda Silka in Chapter 4 examine how the Lowell community can better encourage culturally based economic development in their own backyard. This chapter emphasizes the strength of the community and presents an alternative to the view of Southeast Asian immigrants as needy recipients of public assistance. Two development approaches are discussed: A corporate center approach in which commercial properties and real estate development are attracted to Lowell, and a community based approach where the local government targets the development and expansion of locally owned businesses. The authors are critical of how Lowell officials have adopted a more corporate-centered approach by seeking to attract outside firms to the community. Officials sought to bring in what they perceived as high growth sectors of tourism and high end services. This approach, unfortunately, is unlikely to benefit low income and ethnic minorities directly. These authors suggest that officials simply do not recognize the organic economic possibilities within the immigrant community. The potential of making visible and marketable Southeast Asian cultures via restaurant and specialty shops, and cultural events, has not been sufficiently capitalized upon. As well, divisive homeland politics often undermined potential community development. For instance, Cambodia is 
characterized by a highly divisive and controversial political environment, and its controversies are often carried over transnationally to Cambodian communities in the United States. The authors warn that community developers must understand that homeland politics can be a very sensitive and fractious element in Lowell and other Southeast Asian communities.

The next two chapters turn attention to the education of Southeast Asians in Lowell. Reporting on data drawn from a survey and a case-study of six students from Lowell High School, Tuyet-Lan Pho (Chapter 5) discusses how Southeast Asian families negotiated traditional values in their adjustment to life in the United States and how these values influence the academic achievement of their children. A strength of this chapter is its emphasis on traditional values broadly (respect, family obligation, etc.), and its in-depth examination of how these values might interact with immigrant adjustment. This is a refreshing turn from previous research on Southeast Asian families that have cited Buddhist values as possible explanation for their children's lack of academic achievement. Pho's data paint a picture of Southeast Asians as families that support their children in the ways they can, rather than emphasize cultural deficiencies. She found broad values such as respect for authority and family obligation are important for students' school success. However, I wonder about the appropriateness of studying Southeast Asians as a monolithic cultural group. Southeast Asians, despite their obvious similarities, are comprised of diverse ethnic groups with unique histories and family traditions.

In the next chapter, Khin Mai Aung and Nancy Yu focus on one group-Cambodians. They discuss the institutional challenges that Cambodian students in Lowell are up against including their contact with school and police. This chapter is especially beneficial to those that might view Cambodians as part of the model minority stereotype of Asian Americans. In reality, the high dropout rate of Lowell's Cambodian students has serious implications for the life outcomes of students and their families. Students who are unable to connect with their school and its curriculum find it much easier to leave school. Racial profiling by the local police is an issue in this Cambodian community and may initiate students' involvement with the criminal justice system. These data are consistent with other works that report Cambodian students' feelings of invisibility at school and experiences with negative stereotypes in their local communities. Particularly telling was an interview with one Massachusetts judge: "When asked whether Cambodian youth are overrepresented in Lowell's juvenile justice system, Judge Glitzman (2004) pointed out a lack of sufficient disaggregated data to show such trends” (p. 103). It is likely that those working closely with Cambodian children in the school and criminal justice system understand this population's overrepresentation in difficult circumstances. Given their troubles, researchers and policymakers would do well to disaggregate the experiences of Cambodian youth.

Many Southeast Asians come from a Buddhist tradition. The ways in which these traditions and values are adapted to their host society has important implications for their adaptation. The next three chapters (7, 8, and 9) examine how old world homeland traditions, practices, and memories influence the adaptation of Cambodian and Lao families in Lowell. In Chapter 7, Susan Thomson found that the role of monks in Lowell's Buddhist temples represent a means of community engagement, particularly for troubled youth. Monks are often revered members of the community and can serve as a critical middle-man for struggling parents and their troubled teenagers. Thomson suggests that Buddhist teachings that emphasize individual responsibilities can promote civic engagement and help strengthen sense of community in Lowell. While the temple does not operate exactly as it would in Laos and Cambodia (ordaining many young men for short period of time), it has helped to bring children and parents to a 
common middle ground that focuses on honoring respect, responsibility, and culture. Given the troubling involvement with gangs experienced by many Southeast Asian males in Lowell, the temple serves as a balancing influence that brings troubled youth back to the middle path. For example, Thomson noted: "In this way, many Southeast Asian young adults could be encouraged to recognize that by participating in American democracy, they are connecting with their own cultural traditions as well” (p. 126). The temple provided youth with opportunities to engage their community and locate beauty and honor in their family's cultural traditions. The temple represented a positive alternative to the gangs and violence of the streets for young Cambodian and Lao youth. As well, parent-child relations improved as parents developed pride and admiration for their children since involvement with temple life represented an important cultural practice.

Sylvia Cowan in Chapter 8 discusses the particular experiences of the Lao population in Lowell and in the diaspora. Similar to other Southeast Asian youth in Lowell, Lao children must cope with a number of issues including generational conflicts, school related challenges, and identity negotiation. While the Lao in Lowell and elsewhere are attempting to understand and strengthen their Lao identity, as evidenced by the organization of Lao studies conferences in recent years, the community has also joined with Cambodians to promote social and cultural events in Lowell. These communities' historical and geographic ties serve as a basis for community based collaboration. Lao and Cambodian people tend to share Theravada Buddhist traditions. Thus, both the Lao and Cambodians in the United States have had to address the unclear role of religious leaders in their communities. Jeffrey N. Gerson (Chapter 9) describes a legal dispute for control of the largest Buddhist temple in Lowell between two religious camps of the Cambodian community. Aspects of homeland Cambodian politics are painfully relevant in this dispute as charges of corruption and political influence are launched from both sides. Gerson highlights how monks and other leaders clearly adapt to their host society by utilizing the U.S. legal system, though they might still be in part guided by cultural notions of what is appropriate. Nevertheless, what is most disconcerting from this chapter is what this dispute might represent. The author suggests that due to the Cambodian genocide 30 years ago, the ironclad faith Cambodians once held in their religious leaders have been severely weakened. Cambodian society's social and moral order under the Khmer Rouge experienced a terrible disruption. Consequently, even monks are no longer immune from charges of immorality and corruption from the community.

In a somewhat related vein, Leakhena Nou in Chapter 10 adopts a sociological stress framework to understand the ways in which Cambodians in Lowell are still grappling with the ripple effects of the Cambodian genocide. Survivors of the genocide often exhibit symptoms of Post Traumatic Stress Disorder (PTSD) as the result of the traumatic experiences (family separation, starvation, torture, etc.) they may have experienced. She studied what Cambodians themselves report as stressful factors in their lives and the implications of these difficulties for their community. As well, the study found that gender norms and class differences appear to be important moderators for her informants' perceptions of stress and symptoms of PTSD. Moreover, she argues that the survival strategies developed during the genocide period (e.g., betraying friends and family) has resulted in a critical lack of trust among members of the Cambodian community. It was unclear, however, where the empirical support exists for how mistrust in the Cambodian community is linked to members' experiences during the Killing Fields. I would have liked the author to have provided an explanation for this provocative interpretation. Nevertheless, her findings offer some direction for social workers and mental 
health professionals serving this community with regard to how to better address the unique concerns and challenges of the community.

Chapter 11 is entitled Transforming Experiences: When Host Communities become Home Communities and insightfully describes the changes and adjustments that have been made by Southeast Asians in Lowell as they seek to integrate themselves into U.S. society. Similar to Chapter 8's discussion of civic engagement, the authors emphasize how Southeast Asians have been very active in shaping the course of their own communities. Over the years, Silka, a faculty member at the University of Massachusetts in Lowell, has personally witnessed the emergence of diverse perspectives in Lowell and the development of Southeast Asian leaders in the community. She argues that the community's active involvement in its own future can be understood in the context of opportunities available for engagement. This was a particularly hopeful chapter because of its authentic enthusiasm in describing how Southeast Asians have transformed the social and cultural landscape of their own community, and vice-versa. Silka highlights the goodness and possibilities for Southeast Asians in Lowell. The editors finally wrap it up in the final chapter by offering direction for future research. Reminding readers of the challenges that Southeast Asians in Lowell must still confront, including educational inequities, poverty, PTSD, and religious divisions, the editors suggest that future studies would do well to examine further how the refugee experience can be better understood. How might decisions at the local and national level influence the lives of immigrants and refugees in their communities? They also appropriately call for more work to investigate the meaning of diaspora in our globalized system where the movement of people, money, ideas, and traditions are more fluid than any other points in human history.

As noted in Chapter 11, this book has documented how Southeast Asian families in Lowell are transforming their host communities into home communities. Researchers, policymakers, and students should find these readings helpful for learning about an understudied and underserved population. These chapters would be a welcoming surprise to the great majority of Americans that do not yet recognize the different histories and circumstances of Southeast Asians living in the United States. As a teaching tool, this volume is valuable reading for courses in ethnic studies, education, anthropology, and sociology. For scholars, I hope that this volume incites future work in the dynamic field of Southeast Asian American studies. Though these chapters represent a diverse range of topics and disciplinary perspectives, the underlying theme of this collection has been how Southeast Asian families negotiate their hopes and concerns in pursuit of their American dream.

\section{About the Reviewer}

Vichet Chhuon is a PhD candidate in the Gevirtz Graduate School of Education at the University of California, Santa Barbara. His research interests include immigrant adaptation and schooling, Southeast Asian American Studies, and achievement motivation. 


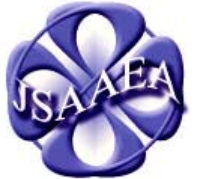

Volume 3

\section{Journal of Southeast Asian American Education \& Advancement} Www.JSAAEA.org

\section{Editor}

Dr. Wayne E. Wright

University of Texas, San Antonio

Associate Editors

Dr. Chhany Sak-Humphry

University of Hawaii

Dr. KimOanh Nguyen-Lam

California State University, Long Beach

Book Review Editor

Dr. Leslie Turpin

School for International Training

Creative Works Editor

Phouang Hamilton

Washington Office of Superintendent of Public Instruction

\section{Special Advisor}

Anne Frank

University of California, Irvine, Southeast Asian Archives

\section{Editorial Assistant \\ Mariana Kuhl}

University of Texas, San Antonio
A peer-reviewed

scholarly journal published by the

National Association

for the Education \&

Advancement of

Cambodian, Laotian,

and Vietnamese

Americans (NAFEA)

Comments and questions for the editorial staff may be directed to jsaaea@lists.sis.utsa.edu

\section{Editorial Review Board}

\author{
Dr. Carl L. Bankston III \\ Tulane University \\ Dr. Phala Chea \\ Lowell Public Schools \\ Dr. Changming Duan \\ University of Missouri, Kansas City \\ Dr. Nancy H. Hornberger \\ University of Pennsylvania \\ Dr. Peter Nien-Chu Kiang \\ University of Massachusetts, Boston \\ Dr. Stacey Lee \\ University of Wisconsin, Madison
}

\author{
Dr. Pollie Bith-Melander \\ Asian and Pacific Islander Wellness Center \\ Dr. George Chigas \\ University of Massachusetts, Lowell \\ Dr. Sophal Ear \\ U.S. Naval Postgraduate School \\ Dr. Samlong Inthaly \\ Minneapolis Public Schools \\ Dr. Kevin K. Kumashiro \\ University of Illinois, Chicago \\ Dr. David Chanpannha Ley \\ Montgomery County Public Schools
}




\author{
Dr. Sue Needham \\ California State University, Dominguez Hills \\ Dr. Max Niedzwiecki \\ Daylight Consulting Group \\ Dr. Clara Park \\ California State University, Northridge \\ Dr. Loan T. Phan \\ University of New Hampshire \\ Dr. Karen Quintiliani \\ California State University, Long Beach \\ Dr. Fay Shin \\ California State University, Long Beach \\ Dr. Yer J. Thao \\ Portland State University \\ Dr. Khatharya Um \\ University of California, Berkeley \\ Dr. Terrence G. Wiley \\ Arizona State University
}

\author{
Dr. Bic Ngo \\ University of Wisconsin-Madison \\ Dr. Leakhena Nou \\ California State University, Long Beach \\ Dr. Mark Pfeifer \\ Texas A\&M University, Corpus Christi \\ Dr. Bounlieng Phommasouvanh \\ Minnesota Department of Education \\ Dr. Kalyani Rai \\ University of Wisconsin, Milwaukee \\ Dr. Nancy J. Smith-Hefner \\ Boston University \\ Dr. Myluong Tran \\ San Diego State University \\ Dr. Linda Trinh Vo \\ University of California, Irvine \\ Dr. Zha Blong Xiong \\ University of Minnesota
}

\begin{tabular}{|c|c|}
\hline \multicolumn{2}{|c|}{$\begin{array}{c}\text { Dr. Kou Yang } \\
\text { California State University, Stanislaus }\end{array}$} \\
\hline \multicolumn{2}{|c|}{ Doctoral Student Editorial Review Board } \\
\hline $\begin{array}{c}\text { Keo Chea } \\
\text { University of Pennsylvania }\end{array}$ & $\begin{array}{l}\text { Vichet Chhuon } \\
\text { University of California, Santa Barbara }\end{array}$ \\
\hline $\begin{array}{c}\text { Loan Dao } \\
\text { University of California, Berkeley }\end{array}$ & $\begin{array}{c}\text { Annie BichLoan Duong } \\
\text { San Joaquin County Office of Education }\end{array}$ \\
\hline $\begin{array}{c}\text { Ha Lam } \\
\text { Arizona State University }\end{array}$ & $\begin{array}{c}\text { Ravy Lao } \\
\text { University of California, Santa Barbara }\end{array}$ \\
\hline $\begin{array}{l}\text { Vanna Som } \\
\text { Harvard University }\end{array}$ & $\begin{array}{l}\text { Rassamichanh Souryasack } \\
\text { University of California, Santa Barbara }\end{array}$ \\
\hline $\begin{array}{l}\text { Giang Pham } \\
\text { University of Minnesota }\end{array}$ & $\begin{array}{c}\text { Layheng Ting } \\
\text { State University of New York, Albany }\end{array}$ \\
\hline $\begin{array}{c}\text { Tinou Tran } \\
\text { University of Houston, Texas }\end{array}$ & $\begin{array}{l}\text { Loan Tran } \\
\text { University of California, Santa Barbara }\end{array}$ \\
\hline $\begin{array}{c}\text { Phitsamay Sychitkokhong } \mathbf{U y} \\
\text { Harvard University }\end{array}$ & $\begin{array}{c}\text { Yang Sao Xiong } \\
\text { University of California, Los Angeles }\end{array}$ \\
\hline
\end{tabular}

